\title{
METODE EKSPERIMENTAL PERKUATAN KOLOM BETON BERTULANG MENGGUNAKAN FRP
}

\author{
Experimental Method Of Strengthening Concrete Columns Using FRP \\ Karmila Achmad $^{1}$, Agoes SMD², Tavio ${ }^{3}$
}

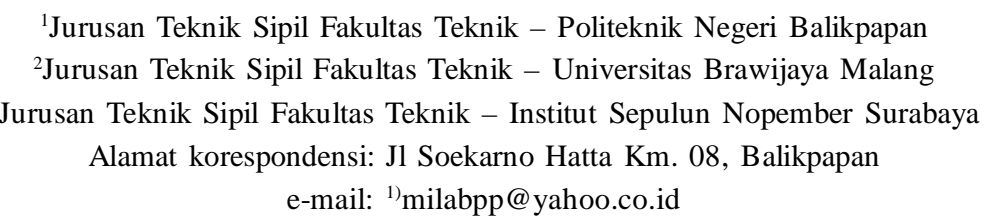

Abstract

The column is an important structure element because the failure of column will have direct impact to other structure components, so that the ruin of structural column is an important thing to be observed. The research use experimental method. The aim of this research is to get improving of strength and ductility in column specimen which is given the FRP strengthener (Fiber Reinforced Polymer) compared with original column. There are 3 specimens used. They are $C-1$ (original column), C-1G (column with GFRP strengthener 1 layer) and C-1C (column with CFRP strengthener 1 layer). From the research got the increasing $P_{\max }$ toward original column is $33,52 \%$ and $54,97 \%$, the increasing of $d_{\max }$ is $6,65 \%$ and $81,18 \%$, also the increasing of $M_{\max }$ is $32,41 \%$ and $55,36 \%$ each for $C-1 G$ and $C-1 C$. Ductility indexes taken on three positions are plastic hinge zone, a half high of column effective and as high as column effective. From analyze result got the increasing of displacement ductility toward C- 1 for $C-1 G$ is $-34,20 \%,-28,46 \%$ and $-12,74 \%$ and $C-1 C$ is $64,48 \%$, $108,74 \%$ and $118,68 \%$, each for plastic hinge zone, a half high of column effective and as high as column effective. In column C-1G happened the decreasing of ductility value because there has been destruction in column head when the test was running.

Key words : Experimental method, FRP, RC, Strengthener column

\begin{abstract}
Abstrak
Kolom merupakan elemen struktur penting karena kegagalan kolom akan berpengaruh langsung terhadap komponen struktur lainnya, sehingga kehancuran kolom struktural merupakan hal yang penting untuk dicermati . Penelitian ini menggunakan metode eksperimen . Tujuan dari penelitian ini adalah untuk mendapatkan meningkatkan kekuatan dan daktilitas dalam spesimen kolom yang diberi FRP penguat ( Fiber Reinforced Polymer ) dibandingkan dengan kolom awal . Ada 3 spesimen yang digunakan . Mereka adalah C - 1 (kolom asli), C - 1G (kolom dengan GFRP penguat 1 lapisan ) dan C - 1C ( kolom dengan CFRP penguat 1 lapisan ). Dari penelitian mendapat peningkatan Pmax menuju kolom awal adalah $33,52 \%$ dan 54,97 \%, peningkatan dmax adalah $6,65 \%$ dan $81,18 \%$, juga meningkatnya Mmax adalah 32,41 \% dan 55, 36 \% masing-masing untuk C - 1G dan C - 1C . Indeks daktilitas diambil pada tiga posisi yang zona sendi plastis, setengah tinggi kolom yang efektif dan setinggi kolom yang efektif. Dari hasil analisis mendapat peningkatan daktilitas terhadap - C 1 untuk C - 1 G adalah $-34,20 \%,-28,46 \%$ dan $-12,74 \%$ dan C - 1C adalah $64,48 \%, 108,74 \%$ dan $118,68 \%$, masing-masing untuk zona sendi plastis, setengah tinggi kolom yang efektif dan setinggi kolom yang efektif . Dalam kolom C - $1 \mathrm{G}$ terjadi penurunan nilai daktilitas karena sudah ada kerusakan di kepala kolom saat tes berjalan .
\end{abstract}

Kata kunci : metode eksperimental, FRP, RC, kolom Strengthener

\section{PENDAHULUAN}

Struktur kolom merupakan elemen struktur yang rentan terhadap kegagalan ketika menerima beban yang besar (ledakan atau seismik), peningkatan beban (meningkatkan penggunaan atau perubahan fungsi struktur) dan degradasi kekuatan (akibat korosi tulangan baja dan reaksi alkali). 
Sebagaimana diketahui bahwa kolom merupakan elemen struktur yang penting karena kegagalan kolom akan berakibat langsung terhadap komponen struktur lainnya. Sehingga dalam suatu struktur keruntuhan kolom struktural merupakan hal yang sangat penting untuk ditinjau.

Ketika struktur bangunan mengalami perubahan fungsi yang berakibat pada meningkatnya beban dari beban rencana maka perlu dicari solusi agar kolom tersebut masih bisa dimanfaatkankan tanpa harus mengganti dengan struktur kolom yang baru. Untuk menyelesaikan permasalahan struktur seperti yang diuraikan diatas, maka penelitian ini akan menawarkan solusi dengan cara memanfaatkan kemajuan teknologi berupa penggunaan material Fiber Reinforced Polymer (FRP) untuk perkuatan eksternal struktur kolom. Keunggulan dari perkuatan FRP ini yaitu bahan lebih ringan, kekuatan tarik tinggi, tidak terjadi korosi sehingga memiliki durabilitas (keawetan) yang tinggi, mudah dalam pemasangannya sehingga menghemat waktu serta bahannya mudah untuk dibentuk (fleksibel). Pada umumnya perkuatan FRP yang digunakan untuk konstruksi adalah CFRP (Carbon Fiber Reinforced Polymer) dan GFRP (Glass Fiber Reinforced Polymer).

\section{Fiber Reinforced Polymer (FRP)}

Fiber Reinforced Polymer (FRP) adalah inovasi perkuatan komposit yang saat ini banyak digunakan sebagai perkuatan eksternal tambahan pada struktur karena sifatnya setelah dipasang pada struktur beton mampu menghilangkan kekurangan beton yang getas menjadi struktur yang ductile. Komposit FRP dapat menjadi alternatif yang murah untuk memulihkan atau meningkatkan kinerja yang ada pada kolom beton (Benzaid, 2008). Dua jenis serat yang umum digunakan untuk perkuatan struktur adalah: Glass Fiber Reinforced Polymer (GFRP) dan Carbon Fiber Reinforced Polymer (CFRP).

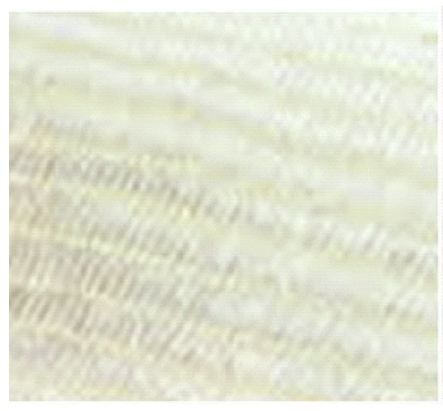

(a)

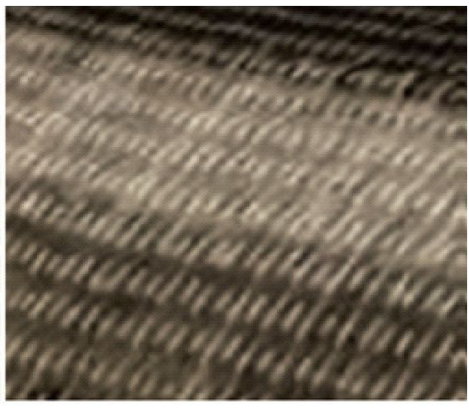

(b)

Gambar 1. Serat yang digunakan: (a)Tyfo ${ }^{\hat{a}}$ SEH System Uni-directional glass composite; (b).Tyfo ${ }^{\hat{a}}$ SCH System Uni-directional carbon composite (Brosur Tyfo ${ }^{\grave{O}}$ Fibrwrap $^{\grave{O}}$ System)

\section{Kolom}

Kolom adalah batang tekan vertikal dari rangka (frame) struktural yang memikul beban dari balok. Kolom meneruskan beban-beban dari elevasi atas ke elevasi yang lebih bawah hingga akhirnya sampai ketanah melalui pondasi. Karena kolom merupakan komponen tekan maka keruntuhan pada satu kolom merupakan lokasi kritis yang dapat menyebabkan collapse (runtuhnya) lantai yang bersangkutan dan bahkan ultimate total collapse seluruh struktur (Nawi, 1998).

\section{Perkuatan Struktur}

Perkuatan struktur pada umumnya bertujuan untuk mengembalikan atau meningkatkan kekuatan elemen struktur agar mampu menahan beban sesuai dengan rencana. Umumnya struktur perlu perkuatan bilamana terjadi perubahan fungsi bangunan atau elemen-elemen strukturnya dirancang sesuai tata cara yang lama dimana beban gempa nominalnya lebih rendah dari yang ditetapkan oleh tata cara saat ini. Kemungkinan lain adalah karena struktur tersebut sebelumnya hanya didesain terhadap beban gravitasi saja tanpa memperhatikan beban gempa yang mungkin terjadi. Hal ini akan mengakibatkan kerusakan bahkan kegagalan struktur (Tavio, 2009). 
METODE PENELITIAN

\section{Tempat Penelitian}

Penelitian ini dilakukan di dua tempat. Pembuatan benda uji dilakukan di Laboratorium Bahan Konstruksi dan Laboratorium Struktur Jurusan Teknik Sipil Universitas Brawijaya, Malang. Untuk uji tarik FRP dan pengujian struktur dilakukan di Balai Bahan Bangunan dan Balai Struktur
Puslitbang Teknologi Permukiman Departemen Permukiman dan Prasarana Wilayah, Bandung.

\section{Rancangan Penelitian}

Benda uji yang digunakan ada 3 buah yaitu C1 sebagai kolom kontrol, C-1G yaitu kolom perkuatan 1 lapis GFRP dan C-1C yaitu kolom perkuatan 1 lapis CFRP. Dengan spesifikasi benda uji seperti dalam tabel 1.

Tabel 1. Spesifikasi Benda Uji

\begin{tabular}{|c|c|c|c|c|c|c|c|c|c|c|}
\hline \multirow[b]{2}{*}{$\begin{array}{c}\text { No } \\
\text { Benda } \\
\text { uji }\end{array}$} & \multirow[b]{2}{*}{$\begin{array}{c}\text { Benda } \\
\text { uji } \\
\text { kolom }\end{array}$} & \multirow{2}{*}{$\begin{array}{c}\text { Kuat } \\
\text { tekan } \\
\text { beton, } \\
\text { Mpa }\end{array}$} & \multicolumn{3}{|c|}{ Ukuran Kolom } & \multicolumn{2}{|c|}{ Tulangan } & \multicolumn{3}{|c|}{ FRP komposit jacketing } \\
\hline & & & $\begin{array}{c}\mathrm{B} \\
(\mathrm{mm})\end{array}$ & $\begin{array}{c}\mathrm{H} \\
(\mathrm{mm})\end{array}$ & $\begin{array}{c}\mathrm{L} \\
(\mathrm{mm})\end{array}$ & Long & Trans & $\begin{array}{l}\mathrm{Fu}, \\
\mathrm{MPa}\end{array}$ & $\begin{array}{c}\text { Tebal } \\
\text { / lapis } \\
(\mathrm{mm})\end{array}$ & $\begin{array}{l}\text { Jumlah } \\
\text { Lapisan }\end{array}$ \\
\hline 1 & C-1 & 20,34 & 350 & 350 & 1100 & 8D19 & $\varnothing 10-200$ & - & - & - \\
\hline 2 & $\mathrm{C}-1 \mathrm{G}$ & 20,34 & 350 & 350 & 1100 & 8D19 & $\varnothing 10-200$ & 575 & 1.3 & 1 \\
\hline 3 & $\mathrm{C}-1 \mathrm{C}$ & 20,34 & 350 & 350 & 1100 & 8D19 & $\varnothing 10-200$ & 876 & 1.0 & 1 \\
\hline
\end{tabular}

\section{Setting up}

Pelaksanaan pengujian dilakukan dengan menempatkan benda uji kolom berdiri tegak pada 2 buah rangka baja (loading frame) yang diletakkan di atas lantai kerja yang dikunci pada ujung-ujung balok tumpuan dengan baut. Untuk mendapatkan asumsi yang diinginkan maka dalam penelitian ini dibuat alat bantu tambahan berupa pelat baja masingmasing diletakan pada dasar kolom, samping kolom dan pada kepala kolom. Displacement beton diperoleh dari 18 Linear Variable Displacement Transducer (LVDT). Set-up pengujian secara skematik ditunjukkan dalam Gambar 1.

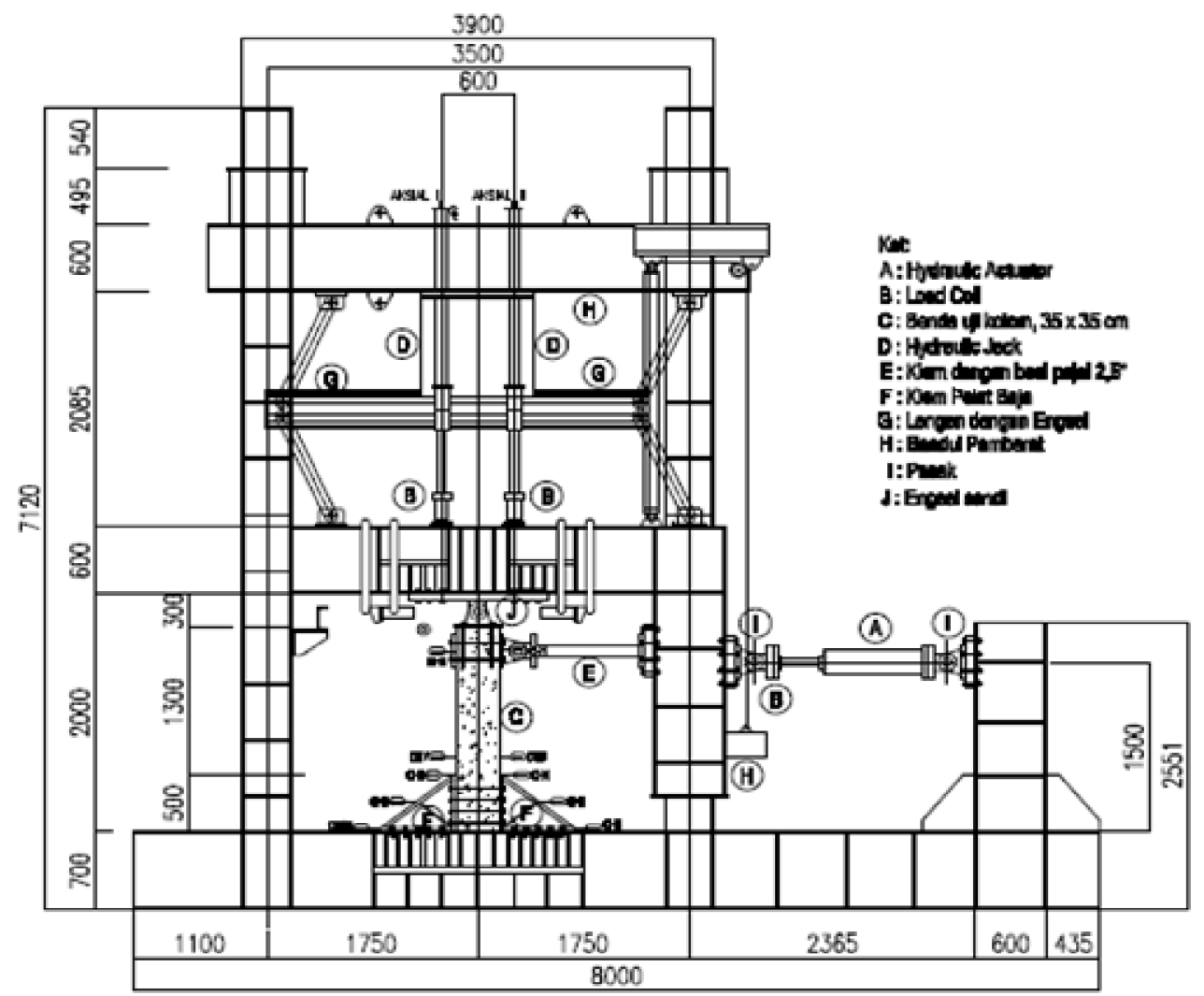

Gambar 2. Setting up pengujian kolom 


\section{Pelaksanaan Pengujian Siklik}

Pengujian spesimen dilakukan setelah benda uji kolom beton berumur diatas 28 hari. Hal ini terkait dengan kesiapan alat pengujian yang akan digunakan. Untuk kolom yang diberi perkuatan CFRP dan GFRP maka perkuatan dipasang setelah beton benar-benar kering kemudian spesimen dibungkus dan dibiarkan pada suhu kamar selama lebih dari 4 hari agar epoksi benar-benar mengeras sebelum pengujian dilakukan.

Pengujian dimulai dengan pemberian beban aksial sesuai dengan perencanaan awal yaitu 748 $\mathrm{kN}$. Selama pengujian, beban aksial yang bekerja adalah konstan dengan variasi beban siklik 181,57 $\mathrm{kN}$ untuk original column, $217,38 \mathrm{kN}$ untuk C-1G dan 225,96 kN untuk C-1C. Pola pembebanan mengacu pada pola pembebanan ACI 374.1-05 dengan rasio drift $\mathrm{D} / \mathrm{L}\left(\mathrm{x} 10^{2}\right): 0,2 ; 0,25 ; 0,35 ; 0,5$; 0,$75 ; 1,0 ; 1,4 ; 1,75 ; 2,20 ; 2,75$ dan 3,5 dan tiga siklus untuk setiap tingkat penyimpangan.

\section{HASIL DAN PEMBAHASAN}

\section{Kegagalan Benda Uji Kolom C-1}

Kegagalan benda uji C-1 akibat spalling beton. Pmax tercapai pada drift 2,75\% siklus pertama dengan nilai $278,9 \mathrm{kN}$. Mulai spalling kolom terjadi pada saat beban mencapai $250,1 \mathrm{kN}$ dengan drift yang sama dengan saat tercapai Pmax yaitu 2,75\% siklus ketiga dengan displacement sebesar 28,42 $\mathrm{mm}$. Spalling ini terjadi pada sisi tekan kolom yang menyebabkan tulangan longitudinal terlihat dengan jelas.

Untuk benda uji C-1 kerusakan paling parah terjadi di kolom bagian bawah yaitu pada zona sendi plastis mulai dari bawah sampai pada ketinggian sekitar $600 \mathrm{~mm}$ diukur dari atas dudukan pelat bawah. Untuk benda uji C-1 kegagalan diakibatkan spalling beton dan hancurnya inti beton serta tekuk tulangan longitudinal. Selain dizona sendi plastis, kerusakan juga terjadi pada kolom bagian atas. Dibagian atas kolom juga terjadi spalling meskipun tidak sebesar dan separah pada zona sendi plastis.

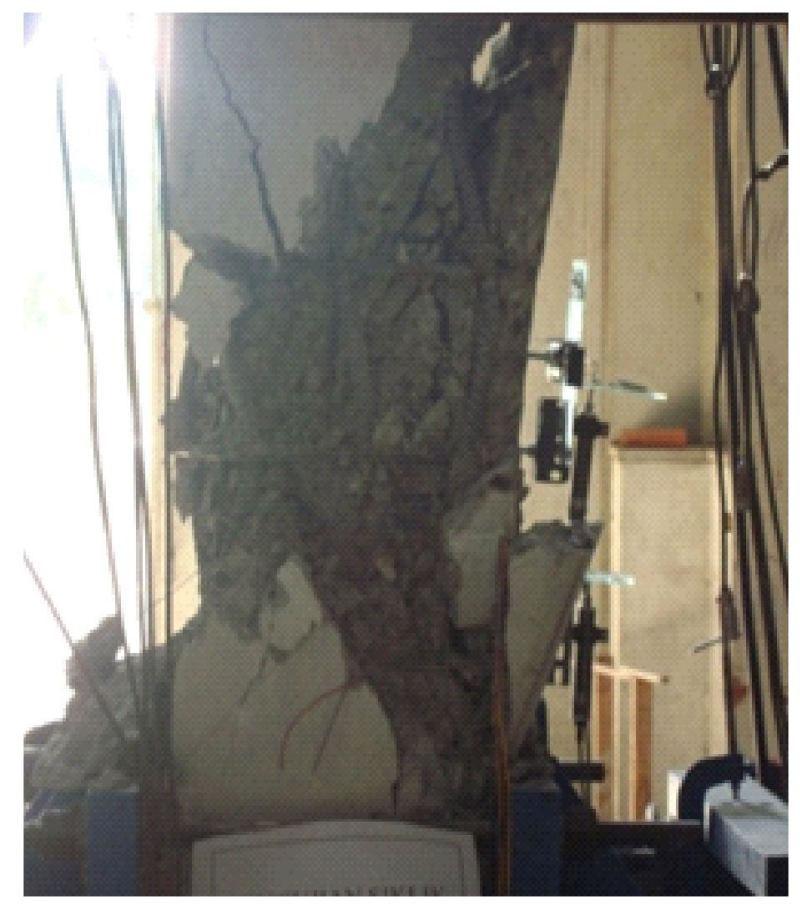

Gambar 3. Kegagalan benda uji C-1

\section{Kegagalan FRP pada Kolom C-1G}

Berbeda dengan C-1, untuk benda uji C-1G, kegagalan kolom ditandai dengan hancurnya beton dan terjadi kegagalan FRP. Dari hasil pengamatan eksperimental menunjukan bahwa FRP tidak pecah sekaligus namun secara bertahap, yang didahului dengan perubahan warna pada resin. Kegagalan dimulai dari beberapa serat di satu lokasi karena terjadi retak beton. Leleh tulangan pertama terjadi pada step 316 yaitu $150,3 \mathrm{kN}$ rasio lateral drift $0,75 \%$ siklus ke dua yang terbaca dari data pada strain gauge 1.

Pada step 728 rasio lateral drift 3,5\% siklus pertama, kepala kolom pecah bersamaan dengan terdengar suara yang nyaring akibat GFRP yang robek. Beton hancur dan GFRP robek dibagian sudut penampang kolom. Kejadian ini sebelumnya ditandai dengan terjadi perubahan warna pada resin dan terdengar bunyi suara merayap. Pada saat yang bersamaan daerah penjepit kolom bagian bawah juga mulai terlihat perubahan warna pada resin berupa garis lurus searah dengan sengkang. Untuk pengujian benda uji C-1G beban puncak yang terbaca adalah $372,4 \mathrm{kN}$ dengan displacament sebesar 38,04 mm.

Pengujian dilanjutkan tanpa adanya beban aksial yang mengakibatkan grafik beban lateraldisplacement munurun secara drastis dan pada 
tahap awal pasca kerusakan kepala kolom, pola grafik beban-displacement menjadi tidak teratur. Ketika beban lateral mencapai $142,6 \mathrm{kN}$ dengan displacement $56,78 \mathrm{~mm}$ mulai terlihat kegagalan GFRP pada zona sendi plastis. Hal ini sudah melampaui displacement rencana sebesar 54,5 mm. Terjadi perubahan warna pada resin yang semakin lama semakin panjang searah dengan tulangan transversal. Pada step 820 bunyi kegagalan GFRP semakin nyaring dengan beban lateral $104,6 \mathrm{kN}$ dan displacement 50,14 mm. Sesuai dengan pola pembebanan yang ada maka pengujian dihentikan pada rasio lateral drift 5\% siklus ke tiga. Pada saat dihentikan kerusakan di zona sendi plastis hanya sampai tahap terjadi perubahan warna pada resin dan kondisi permukaan benda uji sudah tidak merata yang menandakan beton didalam GFRP telah mengalami kerusakan namun GFRP belum pecah.

Ditemukan dua titik kegagalan pada bagian belakang benda uji, masing-masing sepanjang 10 dan $11 \mathrm{~cm}$ serta satu titik kegagalan GFRP sepanjang $18 \mathrm{~cm}$ dibagian depan benda uji.

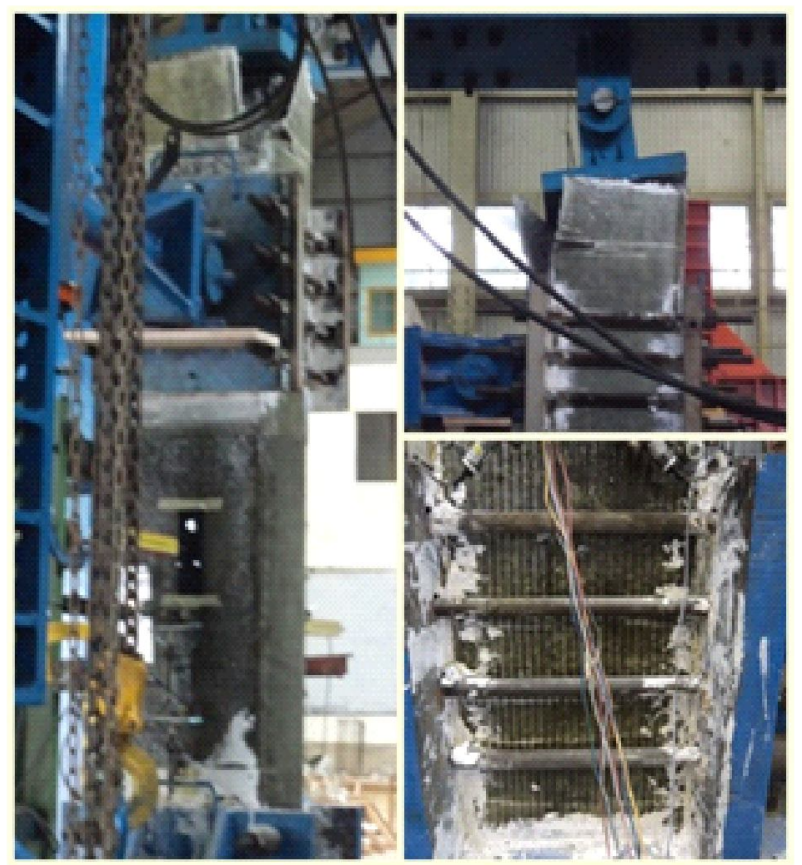

Gambar 4. Kegagalan benda uji C-1G

\section{Kegagalan FRP pada Kolom C-1C}

Sama halnya dengan benda uji C-1G kegagalan kolom C-1C ditandai dengan hancurnya beton dan terjadi kegagalan FRP. Leleh tulangan pertama terbaca pada data strain gauge 3 dengan rasio lateral drift $0,75 \%$ siklus pertama pada step 315 .
Besar beban lateral adalah $168,1 \mathrm{kN}$ dan displacement yang terbaca dari LVDT 2 adalah 7,40 mm. Regangan CFRP putus pada step ke 666 yang terbaca dari data strain gauge 10 pada rasio lateral drift $2,75 \%$ siklus pertama dengan besar beban lateral adalah $347,5 \mathrm{kN}$ dan displacement 29,88 mm yang dibaca dari LVDT 2 .

Pada step 656 rasio lateral drift 2,75\% siklus ke pertama terdengar bunyi dibagian dalam kolom yang menandakan mulai terjadi kerusakan pada beton bagian dalam. Disusul pada step 662 rasio lateral drift $2,75 \%$ siklus pertama dengan beban lateral $124,4 \mathrm{kN}$ terjadi gelembung pada permukaan benda uji di zona sendi plastis bagian samping. Pada step 666 serat CFRP putus dibagian atas penjepit baja pada zona sendi plastis akibat besarnya gelembung pada permukaan beton sepanjang $12 \mathrm{~cm}$. Putusnya serat CFRP ini sampai akhir pengujian bertambah panjang menjadi $35 \mathrm{~cm}$ yaitu sepanjang penampang kolom.

Dari hasil pengamatan eksperimental menunjukan bahwa kegagalan FRP didahului dengan perubahan warna pada resin. Kegagalan dimulai dari beberapa serat di satu lokasi karena terjadi retak beton. Beban puncak terjadi pada step 800 rasio lateral drift 5\% siklus pertama dengan nilai beban lateral $432,2 \mathrm{kN}$ dan displacement yang terbaca dari LVDT 2 adalah 54,4 mm. Sampai dengan akhir pola pembebanan yang diacu yaitu 5\% siklus ke tiga kondisi kolom secara keseluruhan masih baik dan kondisi ultimate benda uji belum tercapai. Sehingga rasio lateral drift ditingkatkan menjadi 5,5\%,6\%, $7 \%$ dan berakhir di rasio lateral drift $8,5 \%$ siklus ke tiga,

Mulai rasio lateral drift 5,5\% siklus kedua terdengar bunyi merayap yang berkelanjutan sampai dengan akhir pengujian yang menandakan beton bagian dalam telah hancur. Sampai akhir pengujian rasio lateral drift $8,5 \%$ siklus ke tiga secara visual kemiringan benda uji terlihat dengan jelas dan nilai displacement yang diperoleh dari data LVDT 2 adalah $96,46 \mathrm{~mm}$ yang meningkat $77,81 \%$ dari displacement rencana sebesar $54,25 \mathrm{~mm}$. Ketika nilai ultimate tercapai maka pengujian langsung dihentikan, hal ini bertujuan untuk menjaga kondisi peralatan.

Kegagalan yang terjadi sampai akhir pengujian pada zona sendi plastis berupa perubahan warna pada resin. Pada sisi samping kiri, kerusakan berupa 
putusnya fiber searah tulangan transversal sepanjang penampang kolom yang berlanjut kebagian depan benda uji sepanjang $3 \mathrm{~cm}$, Untuk bagian depan sendiri juga terjadi perubahan warna pada resin masing-masing sepanjang $1 \mathrm{~cm}$ dan 15 $\mathrm{cm}$ searah tulangan transversal. Sedangkan kegagalan kolom bagian samping kanan berupa perubahan warna pada resin yang sudah berupa luasan pada permukaan benda uji. Kerusakan ini setinggi $30 \mathrm{~cm}$ sepanjang penampang kolom. Untuk permukaan kolom zona sendi plastis secara keseluruhan sudah tidak rata akibat rusaknya beton dibagian dalam.

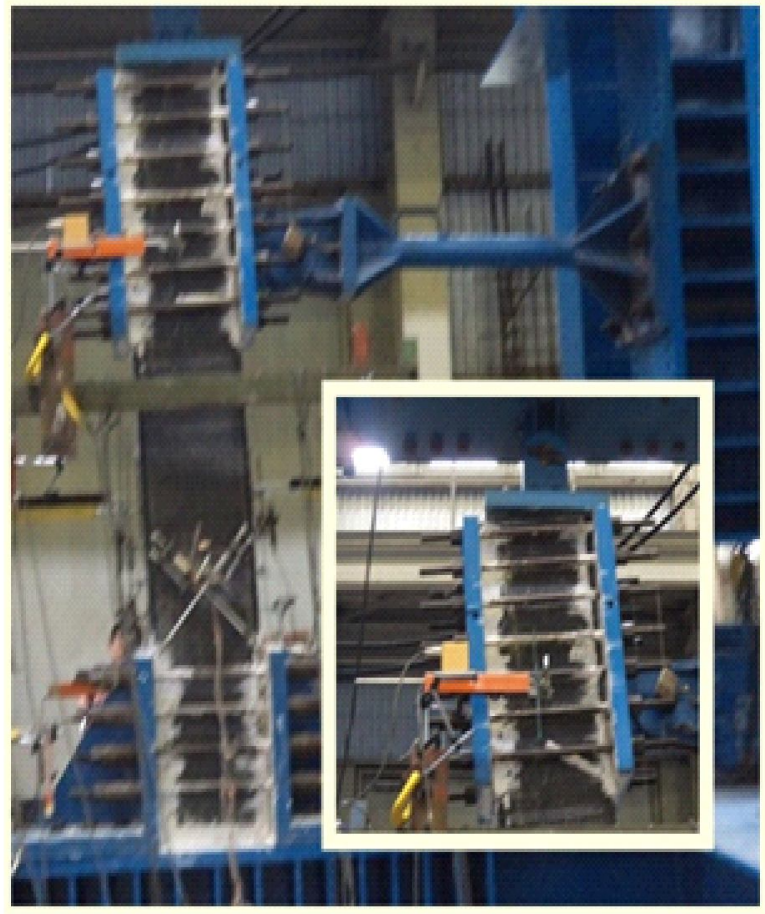

Gambar 5. Kegagalan benda uji C-1C

\section{Beban Lateral-Displacement}

Grafik P-d merupakan data yang dibaca dari load cell berupa beban siklik dari LVDT 2 untuk displacement. LVDT 2 adalah alat pembaca displacement yang terletak di bagian atas kolom dimana tingginya sama dengan tinggi efektif kolom dengan posisi yang berseberangan dengan actuator samping kolom selaku penerus beban siklik.

Dari grafik P-d dapat kita tentukan fenomena yang terjadi selama pengujian untuk specimen $\mathrm{C}-1$, $\mathrm{C}-1 \mathrm{G}$ dan $\mathrm{C}-1 \mathrm{C}$. Besarnya $\mathrm{P}_{\max }$ yang terjadi adalah $278,9 \mathrm{kN} ; 372,4 \mathrm{kN}$ dan $432,2 \mathrm{kN}$ serta $\mathrm{d}_{\max }$ yang terjadi adalah 53,24 mm; 56,78 $\mathrm{mm}$ dan $96,46 \mathrm{~mm}$ berturut-turut untuk C-1, C-1G dan C-1C.
Selain grafik P-d yang dibentuk dari pembacaan data LVDT 2 maka untuk mendapatkan nilai displacement ductility pada 3 posisi yaitu zona sendi plastis, setengah tinggi efektif kolom dan setinggi efektif kolom maka dibuat grafik P-d dari pembacaan data LVDT 3 dan LVDT 5. Grafik P-d yang diperoleh dari pengujian $\mathrm{C}-1, \mathrm{C}-1 \mathrm{G}$ dan $\mathrm{C}-1 \mathrm{C}$ secara lengkap ditampilkan pada gambar 6,7,8.

(a) zona sendi plastis

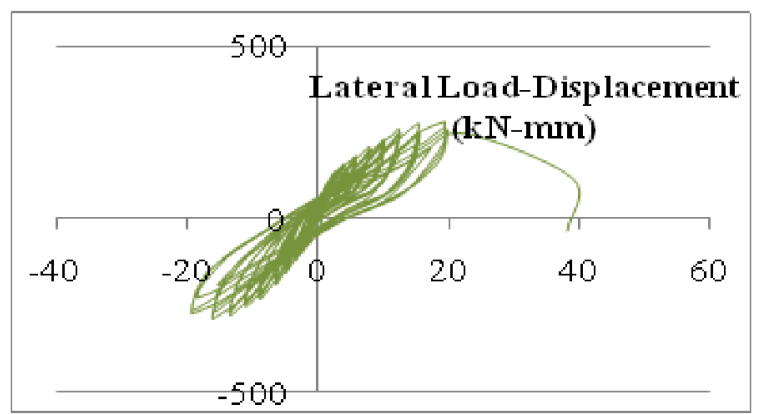

(b) Setengah tinggi kolom efektif

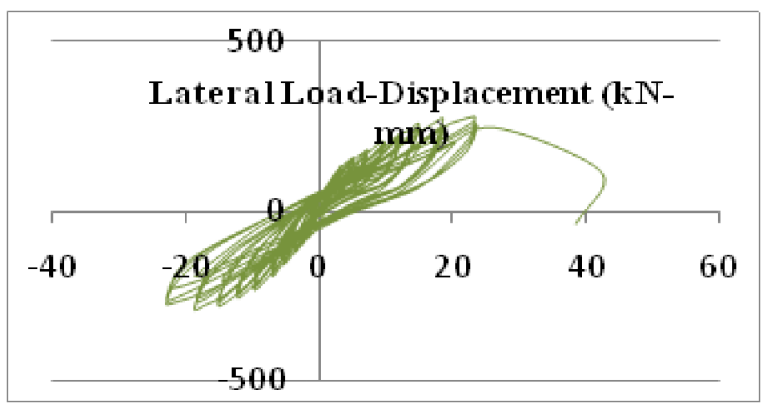

(c) Setinggi efektif kolom

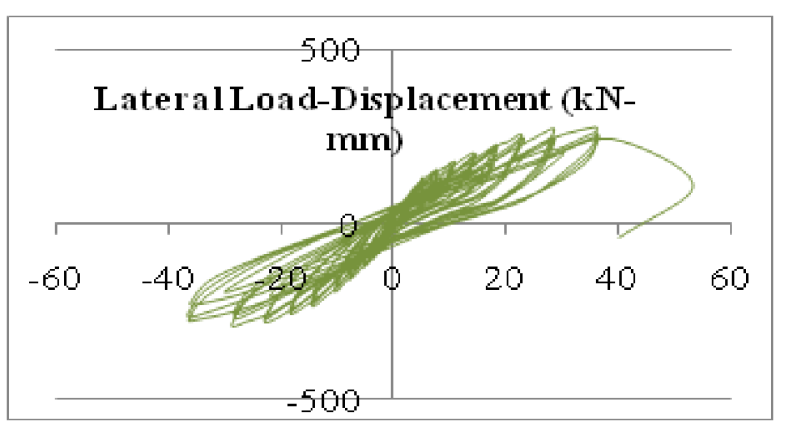

Gambar 6.Grafik beban lateral-displacement C-1

(a) Zona sendi plastis

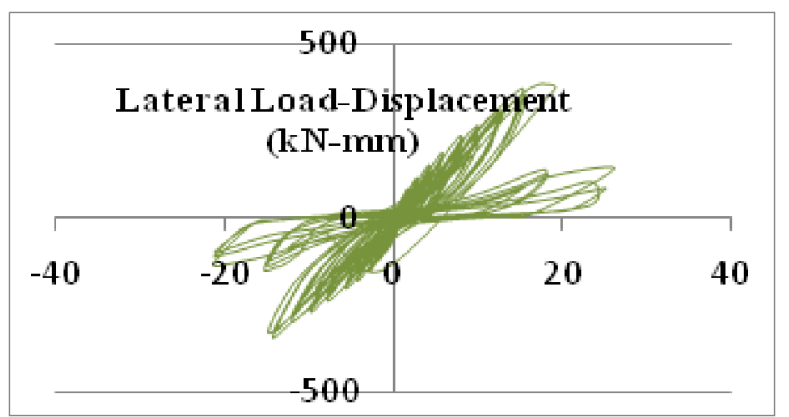


(b) Setengah tinggi efektif kolom

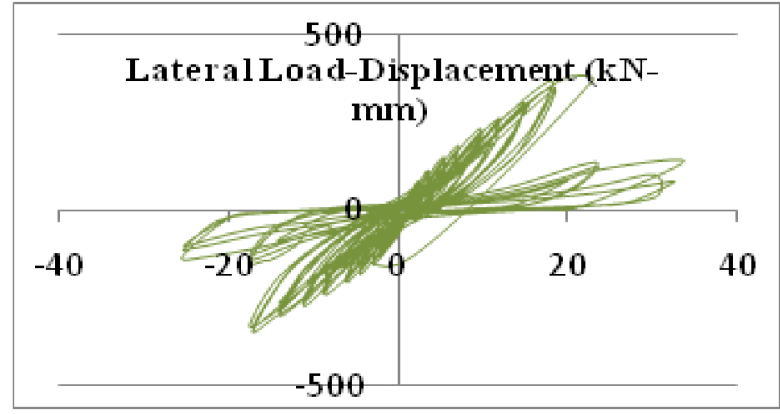

(c) Setinggi efektif kolom

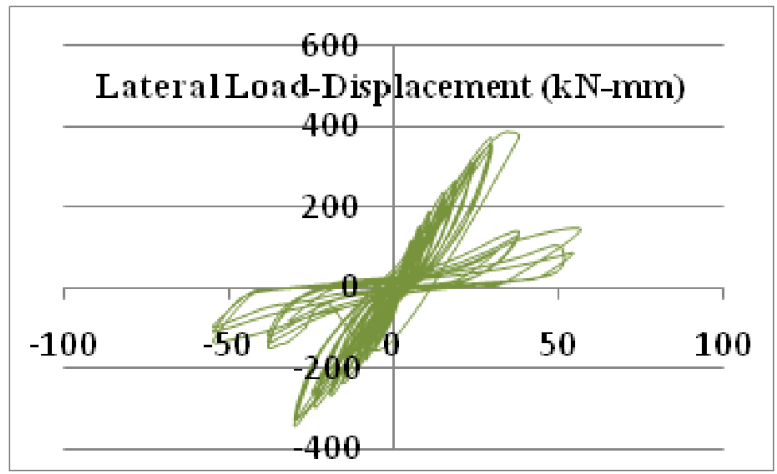

Gambar 7. Grafik beban lateral-displacement C$1 \mathrm{G}$

(a) zona sendi plastis

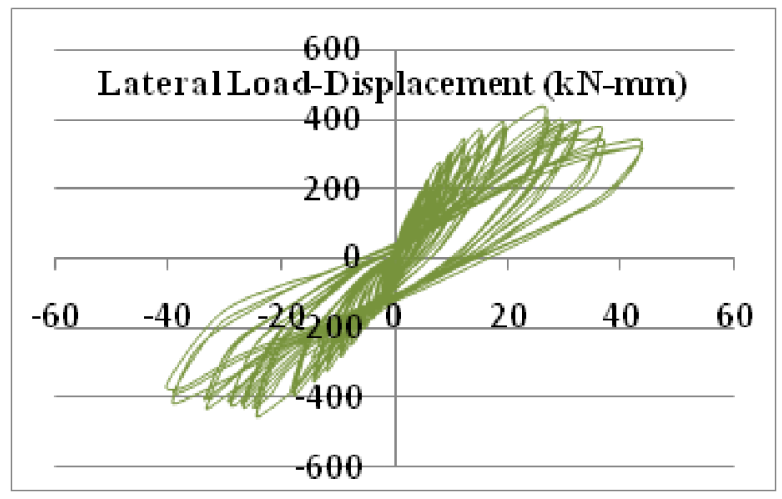

(b) Setengah tinggi kolom efektif

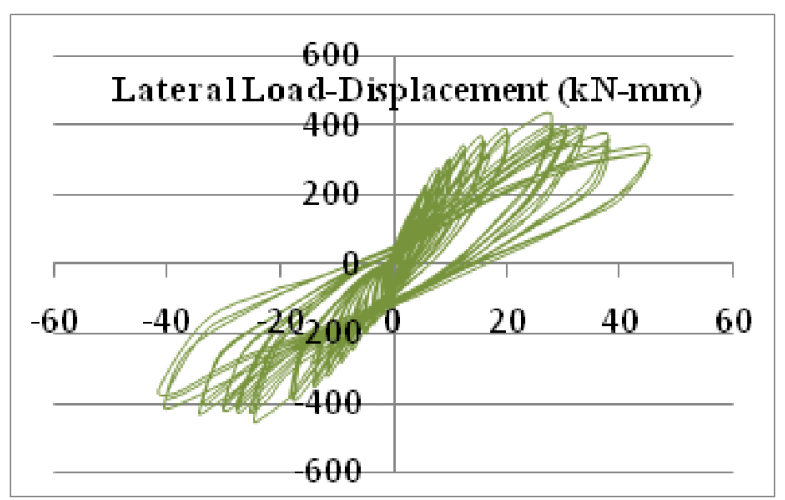

(c) Setinggi efektif kolom

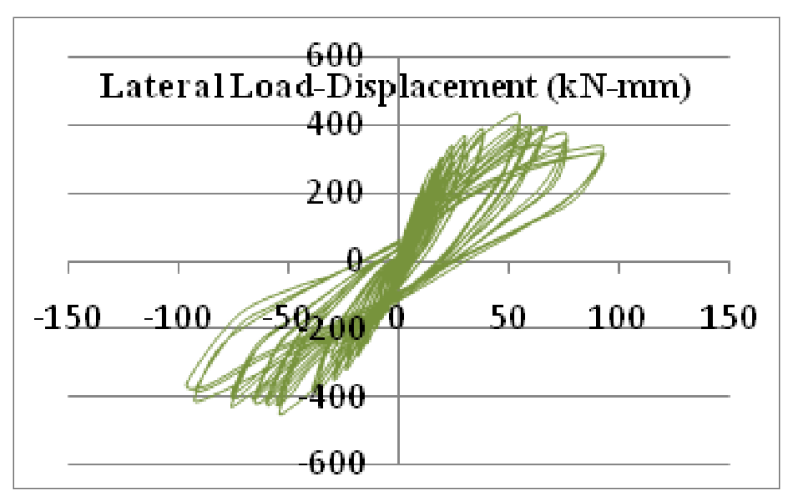

Gambar 8. Grafik Beban-Displacement C-1C

\section{DisplacementDuctility}

Dari skeleton grafik P-d dapat ditentukan besarnya displacement ductility untuk masingmasing benda uji. Nilai displacement ductility diperoleh untuk tiga posisi yaitu zona sendi plastis, setengah tinggi efektif dan setinggi efektif kolom. Untuk benda uji C-1 nilai displacement ductility sebesar 6,70;6,11 dan 5,44, masing-masing untuk zona sendi plastis, setengah tinggi efektif dan setinggi efektif kolom. Nilai displacement ductility $\mathrm{C}-1 \mathrm{G}$ berturut-turut adalah 4,41; 4,37 dan 4,75 untuk zona sendi plastis, setengah tinggi efektif dan setinggi efektif kolom. Nilai ini lebih rendah dari C-1 akibat dari kegagalan pada kepala kolom. Nilai displacement ductility $\mathrm{C}-1 \mathrm{C}$ untuk zona sendi plastis, setengah tinggi efektif dan setinggi efektif kolom adalah 11,$02 ; 12,75$ dan 11,89 . Karena kegagalan kepala kolom yang mengakibatkan pengujian dilanjutkan tanpa beban aksial sehingga terjadi penurunan displacement ductility pada kolom C-1G terhadap C-1 sebesar 34,20\%, 28,46\% dan $12,74 \%$ untuk zona sendi plastis, setengah tinggi efektif dan setinggi efektif kolom. Peningkatan displacement ductility untuk C-1C terhadap C-1 adalah $64,48 \%, 108,74 \%$ dan $118,68 \%$ masingmasing untuk zona sendi plastis, setengah tinggi efektif dan setinggi efektif kolom. 


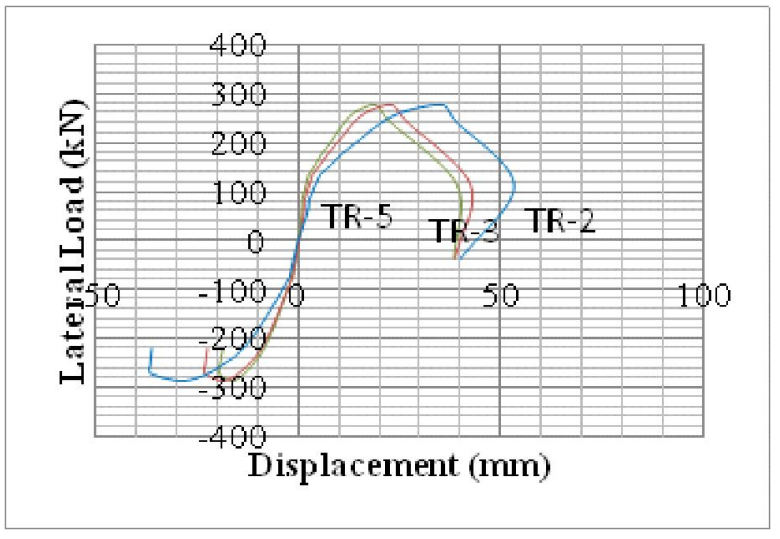

Gambar 9. Skeleton beban lateral-displacement benda uji $\mathrm{C}-1$

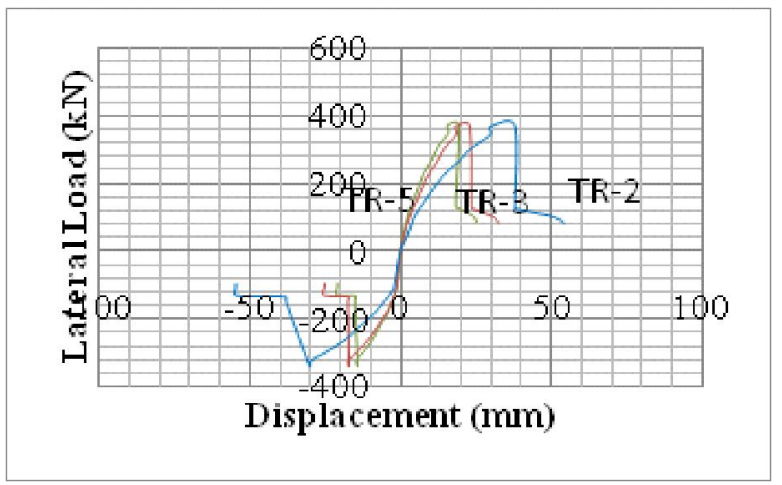

Gambar 10. Skeleton beban lateral-displacement benda uji C-1G

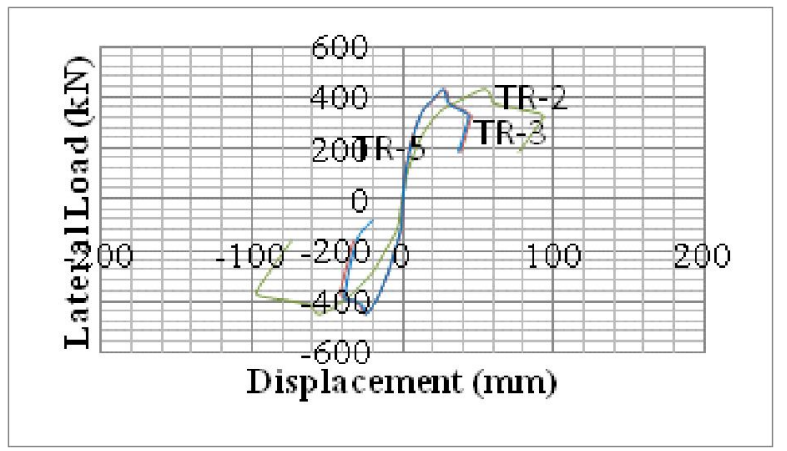

Gambar 11. Skeleton beban lateral-displacement benda uji C-1C

\section{KESIMPULAN DAN SARAN}

\section{Kesimpulan}

Kerusakan pada kolom original terpusat pada daerah sendi plastis yang ditandai dengan tulangan longitudinal bengkok dan terjadi spalling selimut beton hingga inti beton terlihat. Pada kolom C-1G sampai dengan rasio lateral drift yang diacu yaitu 5\% siklus terakhir, zona sendi plastis tidak mengalami kerusakan yang berarti. Hanya terjadi perubahan warna pada resin dan kondisi permukaan specimen sudah tidak merata yang menandakan beton didalam GFRP telah mengalami kerusakan namun GFRP belum pecah. Ditemukan dua titik kegagalan pada daerah sendi plastis yaitu bagian belakang specimen masing-masing sepanjang 10 dan $11 \mathrm{~cm}$ serta satu titik kegagalan GFRP sepanjang $18 \mathrm{~cm}$ dibagian depan specimen. Pada kolom C-1C sampai dengan rasio lateral drift $8,5 \%$ siklus ke tiga secara visual terjadi kemiringan kolom yang cukup besar melampaui displacement rencana. Kegagalan kolom di zona sendi plastis berupa putusnya beberapa serat carbon disepanjang penampang searah dengan tulangan transversal. Selain itu juga terlihat perubahan warna resin dibeberapa titik sepanjang 1 $\mathrm{cm}$ dan $15 \mathrm{~cm}$ dan perubahan warna resin berupa luasan setinggi $30 \mathrm{~cm}$ dari atas penjepit kolom.

Peningkatan kekuatan:

- Besarnya $\mathrm{P}_{\max }$ yang terjadi saat pengujian berlangsung adalah $278,9 \mathrm{kN}$ untuk C-1, 372,4 $\mathrm{kN}$ untuk C-1G dan $432,4 \mathrm{kN}$ untuk C-1C serta $\mathrm{d}_{\text {max }}$ yang terjadi adalah $53,24 \mathrm{~mm}, 56,78 \mathrm{~mm}$ dan 96,46 mm masing-masing untuk C-1, C$1 \mathrm{G}$ dan $\mathrm{C}-1 \mathrm{C}$. Peningkatan $\mathrm{M}_{\max }$ untuk $\mathrm{C}-1$, C-1G dan C-1C adalah 328,04 kNm, 434,37 $\mathrm{kNm}$ dan 509,63 kNm.

- b. Peningkatan $\mathrm{P}_{\max }$ terhadap $\mathrm{C}-1$ adalah $33,63 \%$ dan $54,97 \%$ untuk C-1G dan C-1C. Peningkatan $\mathrm{d}_{\text {max }}$ adalah $6,65 \%$ dan $81,18 \%$ masing-masing untuk $\mathrm{C}-1 \mathrm{G}$ dan $\mathrm{C}-1 \mathrm{C}$ terhadap C-1. Peningkatan $\mathrm{M}_{\max }$ terhadap $\mathrm{C}-1$ adalah $32,41 \%$ dan 55,36\% untuk C-1G dan C-1C.

Peningkatan daktilitas:

- Nilai displacement ductility untuk daerah sendi plastis, setengah tinggi kolom dan setinggi efektif kolom berturut-turut untuk $\mathrm{C}-1$ adalah 6,$70 ; 6,11$ dan 5,44, C-1G adalah 4,41; 4,37 dan 4,75 serta C-1C sebesar 11,02;12,75 dan 11,89 .

- Prosentase peningkatan $\mathrm{m}_{\mathrm{d}} \mathrm{C}-1 \mathrm{G}$ terhadap C1 adalah $-34,20 \%,-28,46 \%$ dan $-12,74 \%$ dan peningkatan $\mathrm{m}_{\mathrm{d}} \mathrm{C}-1 \mathrm{C}$ terhadap $\mathrm{C}-1$ adalah $64,48 \%, 108,74 \%$ dan $118,68 \%$ untuk zona sendi plastis, setengah tinggi kolom dan setinggi efektif kolom. 


\section{Saran}

- $\quad$ Specimen akan sangat menentukan hasil dari penelitian sehingga desain awal, pembuatan dan perawatan specimen harus mendapatkan perhatian disetiap tahapannya.

- Agar displacement kepala kolom bisa searah dan mengikuti pergerakan dari actuator samping maka sebaiknya alat bantu pelat baja samping dibuat setinggi dari actuator samping ke kepala kolom sehingga kerusakan kepala kolom bisa dihindari.

- $\quad$ Perlu dilakukan peninjauan ulang terhadap pola pembebanan yang akan diacu dalam pengujian sehingga bisa diperoleh kegagalan kolom seperti yang diharapkan.

- $\quad$ Agar mendapatkan perilaku dan hasil yang memiliki tingkat validitas tinggi maka perlu difikirkan untuk menambah variasi dan pengulangan specimen.

\section{DAFTAR PUSTAKA}

ACI 440.2R-02. "Guide for the Design and Construction of Externally Bonded FRP Systems for Strengthening Concrete Structures". ACI Committee 440, 2002

ACI 440.3R-04. "Guide Test Methods for FiberReinforced Polymers (FRPs) for Reinforcing or Strengthening Concrete Structures". ACI Committee 440, 2004

ACI 374.1-05. "Acceptance Criteria for Moment Frames Based on Structural Testing and Commentary". ACI Committee 374, 2005

Al-Sulayfani, B and Al-Taee, H. "Modeling of Stress-Strain Relationship for Fibrous Concrete Under Cyclic Loads" Eng.Tech.Vol.26, No1, 2008, pp. 45-53

Balaguru, P, Nanni, A and Giancaspro, J. "FRP Composites for Reinforced and Prestressed Concrete Structures" Taylor \& Francis Group, New York, 2009

Bank, Lawrence. "Structural Design with FRP Materials" John Wiley \& Sons, INC, Canada, 2006

Benzaid, R, Chikh NE and Mesbah H. "Behaviour Of Square Concrete Column Confined With GFRP Composite Warp", Journal Of Civil Engineering And Management, 2008
Cole, C. and Belarbi, A. "Confinement Characteristics of Rectangular FRPJacketed RC Columns", Proceedings of the Fifth International Symposium on Fiber Reinforced Polymer for Reinforced Concrete Structures (FRPRCS-5), Cambridge, UK, July 16-18, 2001, pp. 823-832.

Dhakal, RP and Maekawa, K. "Post-Peak Cyclic behavior and Ductility of reinforced Concrete Columns"

Fam, AZ and Rizkalla, SH. "Confinement Model for Axially Loaded Concrete Confined by Circular Fiber-Reinforced Polymer Tubes" ACI Structural Journal, July-August, 2001, pp.451-461

Fernandes, R and Gonçalves, M. "Sharp Edge Effects on FRP Confinement of RC Square Columns" Portugal

Gangarao, H, Taly, N and Gangarao, H. "Reinforced Concrete Design with FRP Composites" CRC Press, Prancis, 2007 